\title{
Changes in the physical properties of an Amazonian Inceptisol induced by tractor traffic
}

\author{
Romário Pimenta Gomes ${ }^{1}$, Anderson Cristian Bergamin ${ }^{2}$, Laércio Santos Silva ${ }^{1 *}$, \\ Milton César Costa Campos ${ }^{3}$, Jairo Osvaldo Cazetta', Anderson Prates Coelho', \\ and Edicarlos Damacena de Souza ${ }^{4}$
}

\begin{abstract}
${ }^{1}$ Universidade Estadual Paulista (UNESP), Faculdade de Ciências Agrárias e Veterinárias, Via de Acesso Prof. Paulo Donato Castellane, Jaboticabal, São Paulo, 14884-900, Brasil. "Corresponding author (laerciosantos18@gmail.com).

${ }^{2}$ Universidade Federal de Rondônia (UNIR), Departamento de Agronomia, Av. Presidente Dutra, 2965, Porto Velho, Rondônia, 76801-974 Brasil.

${ }^{3}$ Universidade Estadual do Amazonas, Instituto de Educação, Agricultura e Ambiente, Avenida Djalma Batista 3578, Humaitá, Amazonas, 69005-010, Brasil.

${ }^{4}$ Instituto de Ciências Agrárias e Tecnológicas, Câmpus Universitário, Av. Fernando Corrêa da Costa, n 2367, Rondonópolis, Mato Grosso, 78060-900, Brasil.
\end{abstract}

Received: 24 June 2018; Accepted: 23 November 2018; doi:10.4067/S0718-58392019000100103

\begin{abstract}
With agricultural expansion in Amazonian regions, studies are needed to verify the effect of mechanization on the soils of the regions. This study aimed to assess soil physical attributes under different compaction conditions induced by tractor traffic on a soil of southern Amazonas State, Brazil. Treatments consisted of three compaction levels: conventional soil tillage without additional compaction (CT) and conventional soil tillage with additional compaction with four (CTc4) and eight tractor passes $(\mathrm{CTc} 8)$. An intense increase in soil aggregate diameter was observed in the superficial soil layer $(0.00$ $0.05 \mathrm{~m}$ ) from four tractor passes, decreasing in the successive soil layers $(0.05-0.20 \mathrm{~m})$. Soil density increased up to a depth of $0.10 \mathrm{~m}$. The reduced macroporosity and soil moisture on the soil surface $(0.00-0.05 \mathrm{~m})$ did not significantly alter soil microporosity in the different treatments. For the macroporosity, the $0.00-0.05 \mathrm{~m}$ layer was the most impaired, with a reduction of more than $50 \%$ for the treatments submitted to compaction (CTc4 and CTc8). The penetration resistance for the $0.00-0.05 \mathrm{~m}$ layer was increased by more than $150 \%$ between the treatment without compaction $(\mathrm{CT}=0.88 \mathrm{MPa})$ and compaction $(\mathrm{CTc} 4=2.25 \mathrm{MPa} ; \mathrm{CTc} 8=2.50 \mathrm{MPa})$. These results show a greater caution in the agricultural machinery management in Amazonian soils, which may be aggravated due to the intense water regime in the region.
\end{abstract}

Key words: Compaction, mechanization, multivariate analysis, physical attributes.

\section{INTRODUCTION}

The advance of agriculture in Rondônia State may open the frontiers of agriculture in southern Amazonas State. Considering that the Amazon has a very specific climate and soils, there is a concern that agricultural machinery and technologies be used in this region without sufficient knowledge to predict the consequences. In fact, little is known about the problems related to soil compaction resulting from mechanized operations performed under Amazonian conditions (Bergamin et al., 2010).

The high traffic of agricultural machinery and implements on the soil, together with the high weight per axle, are the main factors of compaction that decrease crop yields (Arvidsson and Hakansson, 2014). These conditions change soil physical quality, which is accentuated by the intensity of machinery passes, thus affecting plant growth and development, mainly the roots (Lipiec et al., 2012). The result of these physical changes is a decrease in productivity over the years and 
an increase in production costs (Collares et al., 2008; Bergamin et al., 2010). For wheat, for example, crop yield can be reduce by up to $10 \%$ in compacted soils (Obour et al., 2018).

In general, compaction process promotes an increased soil density and soil penetration resistance, reducing macroporosity, aeration, and infiltration and storage of water in the soil (Lipiec et al., 2012; Cortez et al., 2014; Deperon Júnior et al., 2016). However, the way and intensity of this process depend on soil type, management, and climate, reflecting mainly on soil water content (Cheong et al., 2010) since there are moisture bands that make the soil more or less susceptible to compaction (Michelon et al., 2009).

In a study conducted under tropical semi-humid climate in the Midwest of Brazil, in an Oxisol under corn cultivation, the machinery traffic affected soil physical attributes up to the $0.10 \mathrm{~m}$ layer (Bergamin et al., 2010), while under an Ultisol in the semiarid of the Northeast region, changes did not exceed the $0.05 \mathrm{~m}$ layer (Cortez et al., 2014). In the Southeast region, under a tropical altitude climate, Cunha et al. (2009) observed a soil compaction in the 0.00-0.20 m layer. In a soil from the South of Brazil with a subtropical climate, Suzuki et al. (2007) observed that the degree of compaction corresponding to critical values of macroporosity $\left(0.10 \mathrm{~m}^{3} \mathrm{~m}^{-3}\right)$ and penetration resistance (2 MPa) were higher in an Ultisol when compared to an Oxisol. According to these authors, the critical values of macroporosity and penetration resistance depend on soil type, climatic conditions, and crop type.

In the Amazon region, soil compaction studies tend to be intensified, due to the conversion of native forest to agricultural use (Oliveira et al., 2015). Currently, the conversion is carried out only for profit and does not consider the soil's ability to support the external forces deforming physical attributes, providing their degradation in the early years of farm. Often, this reflects the lack of previous studies in this alignment for the state of Amazonas, possibly because there was a series of environmental legislation that prohibited the agricultural management in large areas in the state, causing the reduced number of investigations, mainly the physical quality of the soil. In addition, the immensity of the state, lithological diversity, and consequently pedological (Campos, 2009), indicate that the soils present specific characteristics that should be considered, aiming at the more assertive use and planning of agricultural practices by soil class.

Several studies on soil compaction can be found in the literature, but most of them were conducted under Oxisols or Ultisols, probably due to their greater occurrence in Brazil. In addition, these studies were carried out in regions with climate and agricultural activities very different from those found in the Amazon region (Collares et al., 2008; Cunha et al., 2009; Giarola et al., 2009; Roque et al., 2010; Bergamin et al., 2010; Arvidsson and Hakansson, 2014; Cortez et al., 2014). Therefore, these results cannot probably be applied in the Amazonian Inceptisols under equatorial climate conditions. Considering that few scientific studies on soil compaction are developed under the Amazonian conditions, it is imperative that this type of study be conducted in this new agricultural frontier. Thus, this study aimed to assess the physical attributes of an Inceptisol under different compaction conditions induced by tractor traffic in southern Amazonas State.

\section{MATERIAL AND METHODS}

The experiment was installed in an Inceptisol (Cambissolo Háplico alítico plíntico, Brazilian Soil Classification). According to Campos (2009), this soil is predominant in high-field areas in southern Amazonas. The study area was located in the experimental farm of the Institute of Education, Agriculture, and Environment (IEAA/UFAM), Universidade Federal

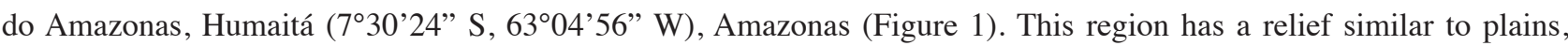
with very small slopes and slightly convex edges. It presents a vegetation of contact between fields and forests, which is characterized by areas that include several campestral formations, with a prevailing small grassy-woody vegetation that alternates with small isolated trees and forest galleries along the rivers (Braun and Ramos, 1959).

The experimental design was a randomized block design with three treatments and 12 replicates (Figure 1). Treatments consisted of three compaction levels: conventional soil tillage without additional compaction (CT), and conventional soil tillage with additional compaction with four (CTc4) and eight tractor passes (CTc8), respectively. Plot dimensions were $5 \times 4 \mathrm{~m}$ (length $\times$ width), totaling $20 \mathrm{~m}^{2}$. Soil compaction induction was performed on 13 November 2011, $2 \mathrm{~d}$ after an intense rainfall, when soil had a water content of $0.28 \mathrm{~kg} \mathrm{~kg}^{-1}$ in the $0.00-0.20$ m layer. An agricultural tractor (MF 4291, Massey Ferguson, Duluth, Georgia, USA) of $140 \mathrm{hp}$ was used in the experiment, presenting diagonal tires, a total mass of $6 \mathrm{Mg}$, and with front and rear tires with pressures of $124 \mathrm{kPa}(14.9-28 \mathrm{R} 1)$ and $137 \mathrm{kPa}(23.1-30 \mathrm{R} 1)$, respectively. Compaction process was performed by passing the tractor wheels on the surface area of the experimental plots. The 
Figure 1. Location and scheme of the experimental area illustrating the tractor traffic direction.

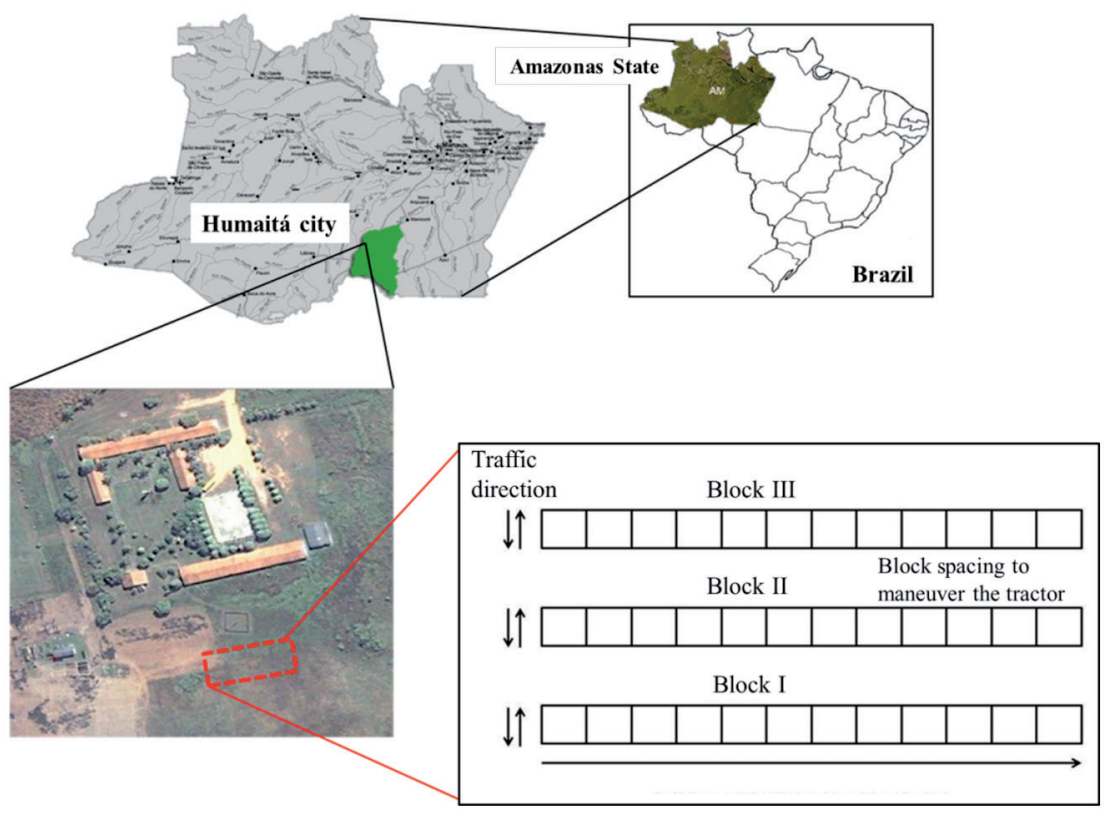

number of passes varied according to the treatment, being the traffic superimposed on the previous one aiming at the same number of passes.

Soil samples with preserved structure were collected from the $0.00-0.05,0.05-0.10$, and $0.10-0.20 \mathrm{~m}$ layers for physical analyses by using volumetric rings with dimensions of $4.0 \mathrm{~cm}$ in height and $4.05 \mathrm{~cm}$. Four samples were taken per layer in order to reduce the risk of losing some replicate. Soil chemical characterization was performed in the $0.00-0.20 \mathrm{~m}$ layer, as well as the particle size analysis, which was determined by the pipette method (Embrapa, 1997). For these analyses a composite sample was obtained from the experimental area from 15 random points. The presented values of clay, silt, and sand of 320,600, and $80 \mathrm{~g} \mathrm{~kg}^{-1}$, respectively, in the first $0.20 \mathrm{~m}$, which means a silty clay loam textured soil. Soil chemical characteristics were determined according to Embrapa (2011) and presented a $\mathrm{pH}\left(\mathrm{H}_{2} \mathrm{O}\right)$ of 4.16, organic matter of $17.1 \mathrm{~g} \mathrm{~kg}^{-1}, 1.38 \mathrm{cmol}_{\mathrm{c}} \mathrm{Ca}^{2+} \mathrm{kg}^{-1}, 1.13 \mathrm{cmol}_{\mathrm{c}} \mathrm{Mg}^{2+} \mathrm{kg}^{-1}, 1.41 \mathrm{cmol}_{\mathrm{c}} \mathrm{Al}^{3+} \mathrm{kg}^{-1}, 5.29 \mathrm{cmol}_{\mathrm{c}} \mathrm{H}+\mathrm{Al}^{3+} \mathrm{kg}^{-1}, 0.01 \mathrm{mg} \mathrm{P} \mathrm{kg}^{-1}, 0.02$ $\mathrm{cmol}_{\mathrm{c}} \mathrm{K} \mathrm{kg}^{-1}, \mathrm{CEC}$ at $\mathrm{pH} 7$ of $7.91 \mathrm{cmol}_{\mathrm{c}} \mathrm{kg}^{-1}$, and base saturation of $32.18 \%$.

Soil samples with preserved structure were saturated by gradually raising the water slide to about $2 / 3$ of the ring height. After saturation, macro $(60 \mathrm{hPa})$ and microporosity (Micro, dry soil) were obtained by the tension table method. Subsequently, samples were dried in an oven at $105-110{ }^{\circ} \mathrm{C}$ for $48 \mathrm{~h}$ in order to determine the volumetric soil moisture (Ms) and bulk density (Sd) by the volumetric ring method (Tormena et al., 1998). Total pore volume (TPV) was calculated by the equation TPV $=(1-\mathrm{Sd} / \mathrm{Pd}) \times 100$. The particle density $(\mathrm{Pd})$ was determined as Blake $(1965)$.

Soil penetration resistance was determined in each plot by using an IAA/Planalsucar impact penetrometer and the results were obtained by calculation according to Stolf $(1991)$ through the equation $\mathrm{SPR}=(5.6+6.89 \times(\mathrm{N} /(\mathrm{A}-\mathrm{B}) \times 10)$ $\times 0.0981$. In this equation, $\mathrm{SPR}$ is the average value of soil penetration resistance $(\mathrm{MPa}), \mathrm{N}$ is the number of impacts of the penetrometer hammer to obtain the reading, and B and A are the readings before and after impacts, respectively (cm). Sampling was performed in the $0.00-0.50 \mathrm{~m}$ layer at intervals of $0.05 \mathrm{~m}$.

Aggregate distribution was determined in three soil layers (0.00-0.05, 0.05-0.10, and 0.10-0.20 m) by the wet sieving method. For this, blocks of soil with preserved structure were taken from the experimental area, being air-dried and sieved in 9.52 and $4.76 \mathrm{~mm}$ sieves. Aggregates retained in the $4.76 \mathrm{~mm}$ sieve were used in the analysis of aggregate stability via wet, which was performed by placing the samples on a set of sieves with meshes of $2.0,1.0,0.50,0.25,0.125$, and 0.063 $\mathrm{mm}$ and submitting them to vertical oscillations for $15 \mathrm{~min}$ at a frequency of 32 oscillations per minute. The mass of the material retained in each sieve was dried in an oven at $105^{\circ} \mathrm{C}$ until constant weight. The percentages of aggregates $>2.00$ $\mathrm{mm}$ and $<2.00 \mathrm{~mm}$, geometric mean diameter (GMD), and weighted mean diameter (WMD) were adopted as stability indices, which were calculated as Kemper and Rosenau (1986). 
Initially, an exploratory statistical analysis of the data was performed. For this, after variable standardization with the null mean and unit variance, the data were submitted to three multivariate statistical approaches: clustering analysis by the hierarchical method using the Euclidean distance as a coefficient of similarity, Ward method as an algorithm to link clusters (Hair et al., 2005), and principal component analysis to discriminate soil samples with specific properties in twodimensional planes generated from the eigenvalues of the covariance matrix obtained from the original variables (Hair et al., 2005). Only eigenvalues higher than the unity were considered in the analyses, according to the criterion proposed by Kaiser (1958). All multivariate statistical analysis was processed using the software Statistica 7.0 (StatSoft, Tulsa, Oklahoma, USA). A univariate statistical analysis was also performed and its results were submitted to ANOVA (F-test) and the means were compared by the Tukey's test at $5 \%$ probability. The univariate statistics were processed using the software ASSISTAT (Silva and Azevedo, 2002).

\section{RESULTS}

In general, in the cluster analysis, the dendrogram (Figure 2) evidenced the formation of two groups in the $0.00-0.05 \mathrm{~m}$ layer and three groups in the 0.05-0.10 and 0.10-0.20 m layers, allowing grouping treatments with characteristics similar to each other. Group 1 (GI) was composed of CT in the 0.00-0.05 and 0.05-0.10 m layers, which presented the lowest

Figure 2. Dendrogram resulting from the hierarchical cluster analysis showing the formation of groups (G) according to the analyzed soil physical variables. $A=0.00-0.05 \mathrm{~m}$ layer; $B=0.05-0.10 \mathrm{~m}$ layer; $C=0.10-0.20 \mathrm{~m}$ layer.
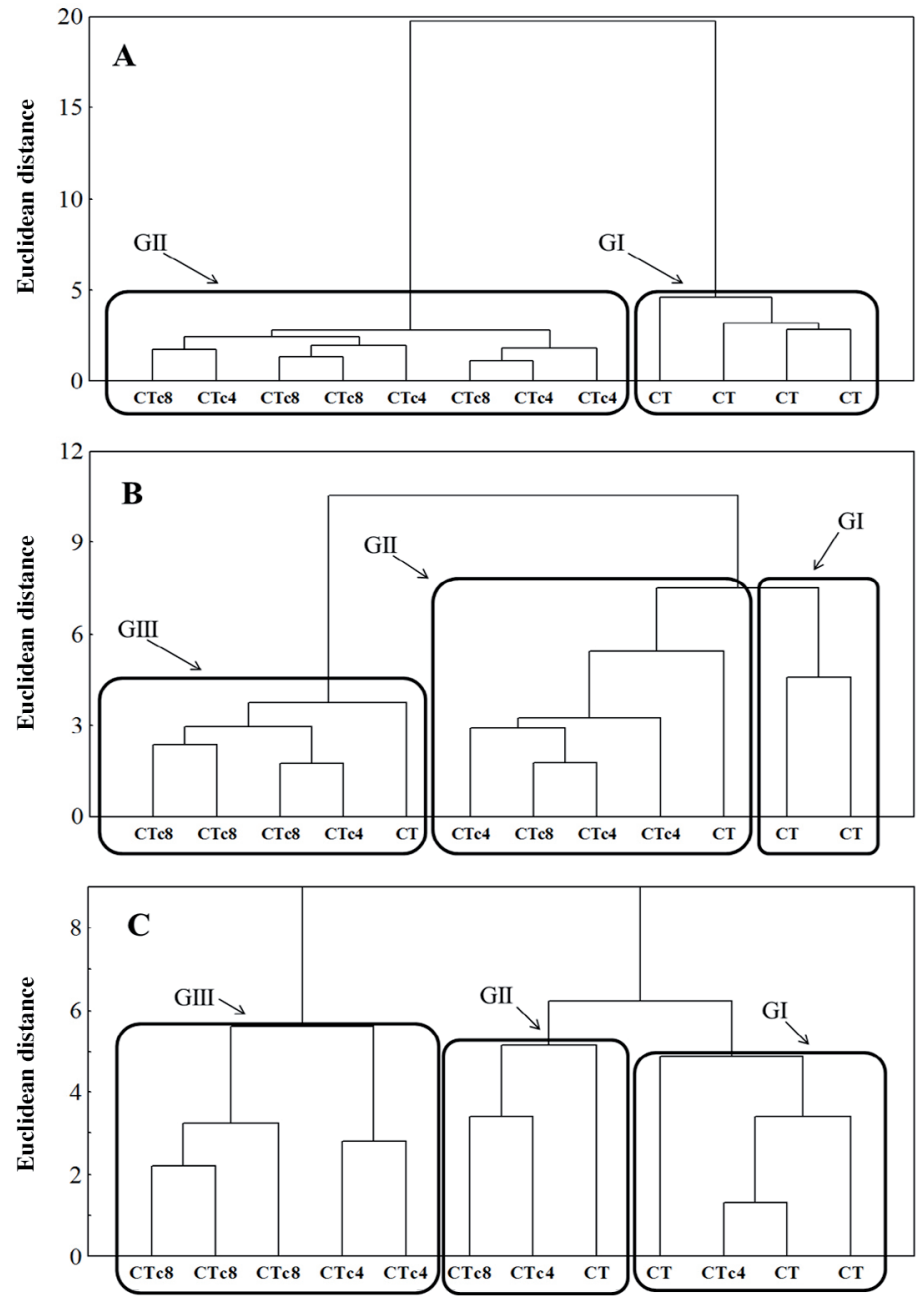

CT: Conventional soil tillage without additional compaction; CTc4 and CTc8: conventional soil tillage with additional compaction by a $6 \mathrm{Mg}$ tractor traffic with four and eight passes, respectively. 
values of Ds, SPR, and diameter $<2 \mathrm{~mm}$. The 0.10-0.20 m layer was composed of CT and CTc4, which did not effectively influence soil physical attributes, considering that soil surface layer receives all applied pressure, with the dissipation of compaction pressure as it enters the soil profile (Figure 2).

The second group (GII) was composed of CTc4 and CTc8 in the 0.00-0.05 m layer, being characterized by higher values of SPR, Ds, and diameter $<2 \mathrm{~mm}$, as well as lower values of GMD, WMD, diameter $>2 \mathrm{~mm}$, Ms, total porosity (Pt), and Macro, while the other layers included all treatments (CT, CTc4, and CTc8) (Figure 2). On the other hand, the third group (GIII) was composed mainly of treatments with additional soil compaction (CTc4 and CTc8).

Principal component analysis (PCA) was applied in order to verify the relationship between soil attributes and soil tillage systems. The set of physical attributes was used for the studied layers considering only the first two factorial axes (Figure 3). Regarding the percentage of variance explained by the principal components, PC1 and PC2 were responsible for $89.39 \%$ of the total variance in the $0.0-0.05 \mathrm{~m}$ layer (79.61\% in PC1 and $9.78 \%$ in PC2), $69.81 \%$ in the $0.05-0.10 \mathrm{~m}$ layer $(43.41 \%$ in PC1 and $26.40 \%$ in PC2), and $60.83 \%$ in the $0.10-0.20 \mathrm{~m}$ layer $(42.10 \%$ in PC1 and $18.73 \%$ in PC2) (Figure 3).

From PCA, variables with the greatest discriminatory potential for each treatment were identified (Table 1). The eigenvectors can be considered as a measure of the relative importance of each variable in relation to the principal components, with positive or negative signals indicating directly or inversely proportional relations, respectively. In the sequence $(0.05-0.10 \mathrm{~m})$, the diameters $>2 \mathrm{~mm}$ and $<2 \mathrm{~mm}$, Ds, Ms, and Pt most correlated in PC1 and GMD in CP2. Moreover, in the $0.10-0.20 \mathrm{~m}$ layer, $\mathrm{Ms}, \mathrm{Pt}$, and Micro contributed to $\mathrm{PC} 1$ and the aggregates $>2 \mathrm{~mm}$ and $<2 \mathrm{~mm}$ to $\mathrm{PC} 2$.

The univariate analysis showed that the different tractor passes changed the values of GMD, WMD, $>2.00$, and $<2.00$ only in the surface layer (0.00-0.05 m) (Table 2). SPR was changed up to the arable layer of $0.20 \mathrm{~m}$ (Table 3), as well as moisture and porosity, as verified by other authors (Bergamin et al., 2010; Deperon Júnior et al., 2016).

Figure 3. Principal component analysis of soil physical attributes. Geometric mean diameter (GMD), weighted mean diameter (WMD), aggregates larger than $2 \mathrm{~mm}(>2.00 \mathrm{~mm})$, aggregates smaller than $2 \mathrm{~mm}(<2.00 \mathrm{~mm})$, soil penetration resistance (SPR), soil density (Ds), volumetric soil moisture (Ms), total porosity (Pt), Macroporosity (Macro), and Microporosity (Micro). $\mathrm{A}=\mathbf{0 . 0 0 - 0 . 0 5} \mathrm{m}$ layer; $\mathrm{B}=\mathbf{0 . 0 5 - 0 . 1 0} \mathrm{m}$ layer; $\mathrm{C}=\mathbf{0 . 1 0 - 0 . 2 0} \mathrm{m}$ layer .
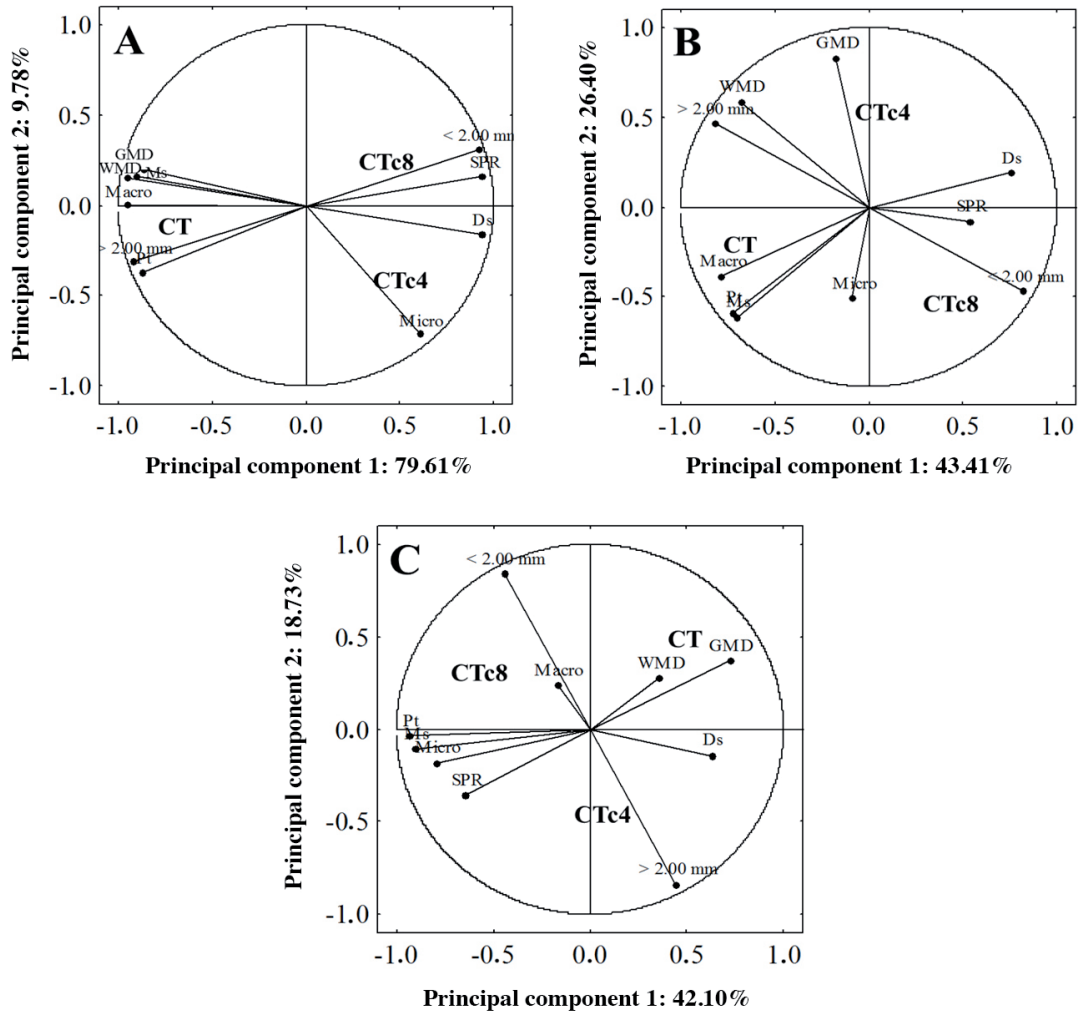

CT: Conventional soil tillage without additional compaction; CTc4 and CTc8: conventional soil tillage with additional compaction by a $6 \mathrm{Mg}$ tractor traffic with four and eight passes, respectively. 
Table 1. Correlation between each principal component (PC) and soil physical attributes. Geometric mean diameter (GMD), weighted mean diameter (WMD), aggregates larger than $2 \mathrm{~mm}(>2.00 \mathrm{~mm})$, aggregates smaller than $2 \mathrm{~mm}(<2.00$ $\mathrm{mm})$, soil penetration resistance (SPR), soil density (Ds), volumetric soil moisture (Ms), total porosity (Pt), macroporosity (Macro), and microporosity (Micro) for different soil layers.

\begin{tabular}{|c|c|c|c|c|c|c|}
\hline \multirow[b]{2}{*}{ Physical attribute } & \multicolumn{2}{|c|}{$0.00-0.05 \mathrm{~m}$} & \multicolumn{2}{|c|}{$0.05-0.10 \mathrm{~m}$} & \multicolumn{2}{|c|}{$0.10-0.20 \mathrm{~m}$} \\
\hline & $\mathrm{PC} 1$ & $\mathrm{PC} 2$ & $\mathrm{PC} 1$ & PC2 & PC1 & PC2 \\
\hline GMD & -0.867265 & 0.196316 & -0.175756 & 0.830038 & 0.722917 & 0.369831 \\
\hline WMD & -0.950431 & 0.156071 & -0.680373 & 0.585819 & 0.359320 & 0.276093 \\
\hline$>2.00 \mathrm{~mm}$ & -0.921405 & -0.310886 & -0.820034 & 0.465679 & 0.443631 & -0.839133 \\
\hline$<2.00 \mathrm{~mm}$ & 0.921405 & 0.310886 & 0.820034 & -0.465679 & -0.443631 & 0.839133 \\
\hline Ds & 0.932388 & -0.159735 & 0.754829 & 0.191086 & 0.629625 & -0.140826 \\
\hline Ms & -0.902266 & 0.163286 & $-\mathbf{- 0 . 7 0 1 3 2 0}$ & -0.613794 & -0.903116 & -0.106040 \\
\hline $\mathrm{Pt}$ & -0.874594 & -0.369766 & -0.726444 & -0.589902 & -0.934702 & -0.036850 \\
\hline Micro & 0.605088 & -0.711620 & -0.087147 & -0.508111 & -0.796845 & -0.182585 \\
\hline Macro & -0.954043 & 0.004126 & -0.786240 & -0.385621 & -0.169580 & 0.238303 \\
\hline SPR & 0.939834 & 0.162885 & 0.536205 & -0.079261 & -0.644422 & -0.358997 \\
\hline
\end{tabular}

More discriminatory values are in bold.

Table 2. Geometric mean diameter (GMD), weighted mean diameter (WMD), aggregates larger than $2 \mathrm{~mm}(>2.00 \mathrm{~mm})$, and aggregates smaller than $2 \mathrm{~mm}(<2.00 \mathrm{~mm})$ in different compaction levels and layers.

\begin{tabular}{|c|c|c|c|c|c|c|}
\hline \multirow[b]{2}{*}{ Treatment } & \multicolumn{3}{|c|}{ GMD (mm) } & \multicolumn{3}{|c|}{ WMD (mm) } \\
\hline & $0.00-0.05 \mathrm{~m}$ & $0.05-0.10 \mathrm{~m}$ & $0.10-0.20 \mathrm{~m}$ & $0.00-0.05 \mathrm{~m}$ & $0.05-0.10 \mathrm{~m}$ & $0.10-0.20 \mathrm{~m}$ \\
\hline CT & $2.16 \mathrm{a}$ & $2.11 \mathrm{a}$ & $1.49 \mathrm{a}$ & $2.78 \mathrm{a}$ & $2.67 \mathrm{a}$ & $2.41 \mathrm{a}$ \\
\hline $\mathrm{CTc} 4$ & $1.51 \mathrm{~b}$ & $1.92 \mathrm{a}$ & $1.26 \mathrm{a}$ & $2.39 \mathrm{~b}$ & $2.65 \mathrm{a}$ & $2.32 \mathrm{a}$ \\
\hline CTc8 & $1.51 \mathrm{~b}$ & $1.83 \mathrm{a}$ & $1.34 \mathrm{a}$ & $2.46 \mathrm{~b}$ & $2.55 \mathrm{a}$ & $2.36 \mathrm{a}$ \\
\hline \multirow[t]{3}{*}{$\mathrm{CV}, \%$} & 25.87 & 37.45 & 18.72 & 11.20 & 11.13 & 16.81 \\
\hline & \multicolumn{3}{|c|}{$>2.00 \mathrm{~mm} \mathrm{( \% )}$} & \multicolumn{3}{|c|}{$<2.00 \mathrm{~mm}(\%)$} \\
\hline & $0.00-0.05 \mathrm{~m}$ & $0.05-0.10 \mathrm{~m}$ & $0.10-0.20 \mathrm{~m}$ & $0.00-0.05 \mathrm{~m}$ & $0.05-0.10 \mathrm{~m}$ & $0.10-0.20 \mathrm{~m}$ \\
\hline $\mathrm{CT}$ & $75.13 \mathrm{a}$ & $65.73 \mathrm{a}$ & $57.57 \mathrm{a}$ & $24.87 b$ & $34.27 \mathrm{a}$ & $42.43 \mathrm{a}$ \\
\hline $\mathrm{CTc} 4$ & $61.91 b$ & $65.25 \mathrm{a}$ & $58.35 \mathrm{a}$ & $38.09 \mathrm{a}$ & $34.75 \mathrm{a}$ & $41.65 \mathrm{a}$ \\
\hline CTc8 & $61.88 b$ & $60.74 a$ & $57.21 \mathrm{a}$ & $38.12 \mathrm{a}$ & $39.26 \mathrm{a}$ & $42.79 a$ \\
\hline $\mathrm{CV}, \%$ & 13.14 & 8.26 & 13.13 & 25.85 & 14.62 & 17.91 \\
\hline
\end{tabular}

Means followed by the same letter in the column do not differ from each other by the Tukey's test at $5 \%$. CT: Conventional soil tillage without additional compaction; CTc4 and CTc8: conventional soil tillage with additional compaction by a $6 \mathrm{Mg}$ tractor traffic with four and eight passes, respectively.

The variables GMD and WMD significantly decreased in the surface layer from four tractor passes, with GMD ranging from 1.49 to $2.16 \mathrm{~mm}$ in $\mathrm{CT}$ and 1.26 to $1.92 \mathrm{~mm}$ in $\mathrm{CTc} 4$ and $\mathrm{CTc} 8$, whereas WMD ranged from 2.41 to $2.78 \mathrm{~mm}$ in CT and 2.32 to $2.65 \mathrm{~mm}$ in $\mathrm{CTc} 4$ and CTc 8 (Table 2). Aggregates $>2 \mathrm{~mm}$ underwent changes in the $0.05 \mathrm{~mm}$ layer from the initial number of passes, presenting results inversely proportional to aggregates $<2 \mathrm{~mm}$, with values of aggregates $>2$ $\mathrm{mm}$ varying from 57.5 to $75.1 \mathrm{~mm}$ in CT and 57.2 to $65.2 \mathrm{in} \mathrm{CTc} 4$ and CTc8, while aggregates $<2 \mathrm{~mm}$ ranged from 24.8 to $42.4 \mathrm{~mm}$ in CT and 34.7 to $42.7 \mathrm{~mm}$ in CTc4 and CTc8 (Table 2).

The variable SPR ranged from 0.88 to $0.93 \mathrm{MPa}$ in CT and 0.91 to $2.50 \mathrm{MPa}$ in CTc4 and CTc8 in the $0.00-0.35 \mathrm{~m}$ layer (Table 3). Two other important and influencing factors of SPR are Ds and Ms. Ds presented variations from 1.12 to 1.40 $\mathrm{Mg} \mathrm{m}^{-3}$ in CT and 1.39 to $1.50 \mathrm{Mg} \mathrm{m}^{-3}$ in CTc4 and CTc8 (Table 4). In addition, Ms presented a small variance throughout the study area, with values ranging from 33.8 to $29.6 \mathrm{~m}^{3} \mathrm{~m}^{-3}$.

Total porosity ranged from 0.47 to $0.55 \mathrm{~m}^{3} \mathrm{~m}^{-3}$ in CT and 0.49 to $0.50 \mathrm{~m}^{3} \mathrm{~m}^{-3}$ in CTc4 and CTc8, differing significantly from CT in relation to CTc4 and CTc8 in the 0.00-0.05 and 0.10-0.20 m layers. In this latter layer, all treatments differed from each other. The coefficient of variation presented values between $8 \%$ and 5\%, low value as Cortez et al. (2014), implying in a higher certainty of the data in relation to this attribute (Table 4).

Soil macroporosity showed a significant difference $(\mathrm{P}<0.01)$ in the $0.00-0.05 \mathrm{~m}$ layer in CTc4 and CTc8 (Table 4). Moreover, this attribute ranged from 0.06 to $0.15 \mathrm{~m}^{3} \mathrm{~m}^{-3}$ in CT and 0.05 to $0.07 \mathrm{~m}^{3} \mathrm{~m}^{-3}$ in CTc4 and CTc8. However, 
Table 3. Soil penetration resistance at different layers and soil compaction levels in an Inceptisol.

\begin{tabular}{lcccc}
\hline & \multicolumn{4}{c}{ Layer $(\mathrm{m})$} \\
\cline { 2 - 5 } & $0.00-0.10 \mathrm{~m}$ & $0.10-0.20 \mathrm{~m}$ & $0.20-0.35 \mathrm{~m}$ & $0.35-0.50 \mathrm{~m}$ \\
\cline { 2 - 5 } Treatment & \multicolumn{4}{c}{ Soil penetration resistance (MPa) } \\
\hline CT & $0.88 \mathrm{~b}$ & $0.87 \mathrm{~b}$ & $0.93 \mathrm{a}$ & $24.87 \mathrm{~b}$ \\
CTc4 & $2.25 \mathrm{a}$ & $1.07 \mathrm{a}$ & $0.91 \mathrm{a}$ & $38.09 \mathrm{a}$ \\
$\mathrm{CTc} 8$ & $2.50 \mathrm{a}$ & $1.07 \mathrm{a}$ & $0.93 \mathrm{a}$ & $38.12 \mathrm{a}$ \\
CV $\%$ & 13.49 & 11.20 & 9.16 & 9.68 \\
\hline
\end{tabular}

Means followed by the same letter in the column do not differ from each other by the Tukey's test at $5 \%$.

CT: Conventional soil tillage without additional compaction; CTc4 and CTc8: conventional soil tillage with additional compaction by a $6 \mathrm{Mg}$ tractor traffic with four and eight passes, respectively.

Table 4. Soil density (Ds), volumetric soil moisture (Ms), total porosity (Pt), macroporosity (Macro), and microporosity (Micro) in different layers and soil compaction levels.

\begin{tabular}{|c|c|c|c|c|c|c|}
\hline \multirow[b]{2}{*}{ Treatment } & \multicolumn{3}{|c|}{ Soil density $\left(\mathrm{Mg} \mathrm{m}^{-3}\right)$} & \multicolumn{3}{|c|}{ Volumetric soil moisture $\left(\mathrm{m}^{3} \mathrm{~m}^{-3}\right)$} \\
\hline & $0.00-0.05 \mathrm{~m}$ & $0.05-0.10 \mathrm{~m}$ & $0.10-0.20 \mathrm{~m}$ & $0.00-0.05 \mathrm{~m}$ & $0.05-0.10 \mathrm{~m}$ & $0.10-0.20 \mathrm{~m}$ \\
\hline $\mathrm{CT}$ & $1.12 \mathrm{~b}$ & $1.34 \mathrm{~b}$ & $1.40 \mathrm{a}$ & $33.86 \mathrm{a}$ & $32.06 \mathrm{a}$ & $29.88 b$ \\
\hline CTc4 & $1.48 \mathrm{a}$ & $1.39 \mathrm{ab}$ & $1.39 \mathrm{a}$ & $29.88 b$ & $30.55 a$ & $30.76 \mathrm{ab}$ \\
\hline CTc8 & $1.50 \mathrm{a}$ & $1.43 \mathrm{a}$ & $1.40 \mathrm{a}$ & $29.68 b$ & $30.61 \mathrm{a}$ & $32.90 \mathrm{a}$ \\
\hline \multirow[t]{3}{*}{$\mathrm{CV}, \%$} & 5.79 & 4.91 & 4.63 & 11.75 & 6.44 & 6.79 \\
\hline & \multicolumn{6}{|c|}{ Total porosity $\left(\mathrm{m}^{3} \mathrm{~m}^{-3}\right)$} \\
\hline & \multicolumn{2}{|c|}{$0.00-0.05 \mathrm{~m}$} & \multicolumn{2}{|c|}{$0.05-0.10 \mathrm{~m}$} & \multicolumn{2}{|c|}{$0.10-0.20 \mathrm{~m}$} \\
\hline $\mathrm{CT}$ & \multicolumn{2}{|c|}{$0.55 \mathrm{a}$} & \multicolumn{2}{|c|}{$0.52 \mathrm{a}$} & \multicolumn{2}{|r|}{$0.47 \mathrm{~b}$} \\
\hline $\mathrm{CTc} 4$ & \multicolumn{2}{|c|}{$0.49 \mathrm{~b}$} & \multicolumn{2}{|c|}{$0.49 \mathrm{a}$} & \multicolumn{2}{|r|}{$0.49 \mathrm{ab}$} \\
\hline CTc8 & \multicolumn{2}{|c|}{$0.49 \mathrm{~b}$} & \multicolumn{2}{|c|}{$0.50 \mathrm{a}$} & \multicolumn{2}{|r|}{$0.50 \mathrm{a}$} \\
\hline $\mathrm{CV}, \%$ & \multicolumn{2}{|c|}{8.84} & \multicolumn{2}{|c|}{7.03} & \multicolumn{2}{|r|}{5.82} \\
\hline & \multicolumn{3}{|c|}{ Macroporosity $\left(\mathrm{m}^{3} \mathrm{~m}^{-3}\right)$} & \multicolumn{3}{|c|}{ Microporosity $\left(\mathrm{m}^{3} \mathrm{~m}^{-3}\right)$} \\
\hline & $0.00-0.05 \mathrm{~m}$ & $0.05-0.10 \mathrm{~m}$ & $0.10-0.20 \mathrm{~m}$ & $0.00-0.05 \mathrm{~m}$ & $0.05-0.10 \mathrm{~m}$ & $0.10-0.20 \mathrm{~m}$ \\
\hline $\mathrm{CT}$ & $0.15 a$ & $0.11 \mathrm{a}$ & $0.06 \mathrm{a}$ & $0.40 \mathrm{a}$ & $0.41 \mathrm{a}$ & $0.40 \mathrm{~b}$ \\
\hline $\mathrm{CTc} 4$ & $0.07 \mathrm{~b}$ & $0.08 \mathrm{a}$ & $0.08 \mathrm{a}$ & $0.42 \mathrm{a}$ & $0.41 \mathrm{a}$ & $0.41 \mathrm{~b}$ \\
\hline CTc8 & $0.07 \mathrm{~b}$ & $0.08 \mathrm{a}$ & $0.05 \mathrm{a}$ & $0.42 \mathrm{a}$ & $0.42 \mathrm{a}$ & $0.45 \mathrm{a}$ \\
\hline $\mathrm{CV}, \%$ & 37.75 & 46.02 & 38.74 & 10.10 & 7.27 & 4.66 \\
\hline
\end{tabular}

CT: Conventional soil tillage without additional compaction; CTc4 and CTc8: conventional soil tillage with additional compaction by a $6 \mathrm{Mg}$ tractor traffic with four and eight passes, respectively. Means followed by the same letter in the column do not differ from each other by the Tukey's test at $5 \%$.

Micro presented inversely proportional amplitudes with macroporosity, with values ranging from 0.40 to $0.41 \mathrm{~m}^{3} \mathrm{~m}^{-3}$ in $\mathrm{CT}$ and 0.41 to $0.45 \mathrm{~m}^{3} \mathrm{~m}^{-3}$ in CTc4 and CTc8, differing significantly in CTc8 in relation to the other treatments in the 0.10-0.20 m layer.

\section{DISCUSSION}

Multivariate statistical techniques were used in this study since they are pointed out as an important tool in the study of soil physical quality indicators (Oliveira et al., 2015), soil management analysis (Mantovanelli et al., 2015; Soares et al., 2016), and crop productivity as a function of soil physical quality (Obour et al., 2018). In fact, they are efficient in distinguishing conventional management with and without additional compaction, demonstrating the simultaneous effect of mechanized tillage on soil physical attributes (Figures 2 and 3). These techniques were also efficient in distinguishing soil physical attributes most related to each treatment (Figures 2 and 3). 
In the cluster analysis, a cut in the Euclidean distance of four clusters was allowed, leading to a division of three groups. This shows the possibility of these attributes be considered as relevant by the multivariate analysis in understanding and planning strategies for an efficient soil use in the Amazon region (Toledo et al., 2009).

Principal component analysis was able to explain $89.39 \%$ (79.61\% in PC1 and $9.78 \%$ in PC2), $69.81 \%$ (43.41\% in PC1 and $26.40 \%$ in $\mathrm{PC} 2$ ), and $60.83 \%$ (42.10\% in PC1 and $18.73 \%$ in PC2) of the total data variance in the $0.00-0.05,0.05$ 0.10, 0.10-0.20 m layers, respectively. In the 0.00-0.05 m layer, GMD, WMD, Macro, Micro, aggregates $>2.00 \mathrm{~mm}$ and $<2.00 \mathrm{~mm}$, SPR, and Ds contributed to the total data variance in PC1 and Micro in PC2 (Figure 3). Due to a great causeand-effect relationship among soil attributes, all these variables reflected changes in most of the physical attributes and, consequently, soil physical quality, which may be considered as strong indicators of compaction process, as also observed by other authors (Bergamin et al., 2010; Stefanoski et al., 2013).

In PC1, only the attributes most associated with aggregate distribution and organization of soil structure (WMD and GMD) were more sensitive in CT, reinforcing that in the absence of induced compaction these variables were strongly changed by the normal conditions of tillage and use of soil. In the 0.00-0.05 layer, GMD decreased from CTc 4 , modifying aggregate structure close to the surface when compared to CT (Table 2). In fact, soils present a greater intensity of the compaction effects on the surface layers (Valicheski et al., 2012). Valicheski et al. (2012) observed that in the 0.00-0.10 $\mathrm{m}$ layer, only the first two tractor passes were enough to cause soil aggregates to rupture, favoring particle approximation and, consequently, promoting soil compaction.

In the 0.05-0.10 and 0.10-0.20 m layers, WMD did not show a significant difference in relation to the surface layer. Studies carried out by Genro Júnior et al. (2004) revealed that the highest compaction level for WMD was close to the $0.10 \mathrm{~m}$ layer, but in this study, it was observed only in the $0.05 \mathrm{~m}$ layer.

The aggregate class $>2.00 \mathrm{~mm}$ in CTc 4 and CTc 8 showed a lower stability in the $0.00-0.05 \mathrm{~m}$ layer when compared to $\mathrm{CT}$ and, consequently, the aggregate class $<2.00 \mathrm{~mm}$ in CTc4 was inversely proportional when compared to the class $>$ $2.00 \mathrm{~m}$ in the same layer (Table 2). Cheong et al. (2010) observed that soil management carried out by using agricultural machinery and implements and the absence of cover crop cultivation provided a lower percentage of aggregates larger than $2 \mathrm{~mm}$ and WMD in the 0.05-0.10 m layer. According to Martins et al. (2010), the absence of soil cover exposes aggregates to external disrupting forces such as rainfall and agricultural management.

Soil penetration resistance, determined in the $0.00-0.10$ and $0.10-0.20 \mathrm{~m}$ arable layers, had a significant increase $(\mathrm{P}<0.01)$ due to an increase in tractor traffic (Table 3). Similarly, Collares et al. (2008) observed that the additional compaction exerted by four tractor passes increased SPR in the more superficial layers, and even when the soil presented a high moisture, resistance values remained above $2 \mathrm{MPa}$, which is limiting to plant growth (Lipiec et al., 2012).

The values of SPR in the $0.20-0.35 \mathrm{~m}$ layer varied from 0.91 to $0.93 \mathrm{MPa}$, differing from the more superficial layers, with nonsignificant influence of the tractor wheels ( $\mathrm{P}>0.01$ ) when compared to TC. Andrade et al. (2013) estimated SPR considered values $\geq 1.9 \mathrm{MPa}$ as indicators of compacted soils, which was not observed in the $0.20-0.35 \mathrm{~m}$ layer of our study. However, the results of SPR presented in Table 3 may help in understanding the pressure required to perform management by using tractors and agricultural implements, which, are the cause of the mechanical impediment to root development.

When analyzing Ds (Table 4), a negative effect of the pressure exerted by the tractor from four passes could be observed in the 0.00-0.05 m layer and, in the 0.05-0.10 m layer, only from eight passes. In the 0.10-0.20 m layer, the increase in compaction did not cause a reducing effect on Ds $(\mathrm{P}>0.01)$. Ds values higher than $1.40 \mathrm{Mg} \mathrm{m}^{-3}$ can be considered as limiting to the growth of some cover plants (Pacheco et al., 2015). Values above this limit were only observed in the 0.00 $0.05 \mathrm{~m}$ layer, reaching $1.48 \mathrm{Mg} \mathrm{m}^{-3}$ in CTc4 and $1.50 \mathrm{mg} \mathrm{m}^{-3}$ in CTc8. However, these values did not exceed the critical density of $1.55 \mathrm{Mg} \mathrm{m}^{-3}$ proposed by Reichert et al. (2003) for medium textured soils, as in our study.

The values of Ms varied inversely when compared to those of Ds and SPR (Table 4), which means that the increased soil compaction restricts its ability to retain water. Therefore, moisture is considered as one of the most important factors in soil resistance due to compaction (Michelon et al., 2009). In the 0.00-0.05 and 0.05-0.10 m layers, Ms presented lower values in CT when compared to CTc4 and CTc8, contrasting with the results of Pezzoni Filho et al. (2014), who worked on an Inceptisol and found higher values of Ms as tractor passes increased. Collares et al. (2008) observed an increase in SPR in the 0.00-0.05 m layer as water content decreased, thus causing an increasing mechanical impediment to the expanding roots. However, intense rainy periods may occur in the Amazon region, leading to water accumulation on the soil surface. 
The variable Pt presented higher values in the 0.00-0.05 and 0.05-0.10 m layers of CT when compared to CTc4 and CTc8 (Table 4). Deperon Júnior et al. (2016) worked on an Ultisol cultivated with corn and observed a higher value of $\mathrm{Pt}$ in the 0.00-0.10 m layer with no tractor traffic. This value was higher when compared to treatments with compaction levels with three, six, and nine tractor passes. On the other hand, Cortez et al. (2014) observed a reduced Pt up to a depth of $0.20 \mathrm{~m}$ in an Ultisol.

Soil macroporosity was influenced by the pressure exerted by tractor wheels, as well as other attributes previously mentioned. In the surface layer of 0.00-0.05 m, CT differed statistically from CTc4 and CTc8, with reduced Macro values ranging from 0.05 and $0.08 \mathrm{~m}^{3} \mathrm{~m}^{-3}$ in treatments with additional soil compaction (Table 4). According to Roque et al. (2010), macroporosity values lower than $0.10 \mathrm{~m}^{3} \mathrm{~m}^{-3}$, i.e. $10 \%$ of the total pores, are considered as limiting to root development. This can be observed in CTc4 and CTc8 reducing soil productive potential.

Treatments with traffic at different compaction levels in the 0.00-0.10 m layer did not significantly change $(\mathrm{P}>0.01)$ Micro. This change was only observed in CTc8 in the 0.10-0.20 m layer (Table 4). Studies carried out by Giarola et al. (2009) on the effect of tillage systems on soil physical attributes also did not observe changes in the micropore volume. However, Bergamin et al. (2010) did not observe changes in soil microporosity even in the 0.20 m layer of CTc6, different from that observed in the studied Amazonian soil.

Thus, Amazon soils undergo changes in their physical and structural quality when submitted to the effects of agricultural machinery management and trafficability of tractors and implements. However, although this soil is susceptible to this management, with each layer varying as a function of each evaluated physical attribute, Amazonian soils respond differently when compared to soils of other regions, being necessary future studies with more deepening and taking into account plant response to this management type.

\section{CONCLUSIONS}

An intense increase in soil aggregate diameter was observed in the superficial soil layer $(0.00-0.05 \mathrm{~m})$ from four tractor passes, decreasing in the successive soil layers $(0.05-0.20 \mathrm{~m})$. Soil density increased up to a depth of $0.10 \mathrm{~m}$. The reduced macroporosity and soil moisture on the soil surface $(0.00-0.05 \mathrm{~m})$ did not significantly alter soil microporosity in the different treatments. These results show a greater caution in the agricultural machinery management in Amazonian soils, which may be aggravated due to the intense water regime in the region.

\section{REFERENCES}

Andrade, R.S., Stone, L.F., e Godoy, S.G. 2013. Estimativa da resistência do solo à penetração baseada no índice $\mathrm{S}$ e no estresse efetivo. Revista Brasileira de Engenharia Agrícola e Ambiental 17(9):932-937. doi:dx.doi.org/10.1590/S1415-43662013000900004.

Arvidsson, J., and Hakansson, I. 2014. Response of different crops to soil compaction-Short-term effects in Swedish field experiments. Soil and Tillage Research 138:56-63. doi:dx.doi.org/10.1016/j.still.2013.12.006.

Bergamin, A.C., Vitorino, A.C.T., Franchini, J.C., Souza, C.M.A., e Souza, F.R. 2010. Compactação em um Latossolo Vermelho Distroférrico e suas relações com o crescimento radicular do milho. Revista Brasileira de Ciência do Solo 34(3):681-691. doi:dx.doi.org/10.1590/S0100-06832010000300009.

Blake, G.R. 1965. Bulk density. p. 374-390. In Black, C.A. (ed.) Methods of soil analysis; physical and mineralogical properties, including statistics of measurement and sampling. American Society of Agronomy, Madison, Wisconsin, USA.

Braun, E.H.G., e Ramos, J.R.A. 1959. Estudo agroecológico dos campos Puciarí-Humaitá (Estado do Amazonas e Território Federal de Rondônia). Revista Brasileira de Geografia 21(4):443-497.

Campos, M.C.C. 2009. Pedogeomorfologia aplicada a ambientes Amazônicos do Médio Rio Madeira. PhD Thesis. 260 p. Universidade Federal Rural de Pernambuco, Recife, Pernambuco, Brasil.

Cheong, L.R.N., Ng Kee Kwong, K.F., Ah Koon, P.D., and Du Preez, C.C. 2010. Influence of sugarcane cropping on the quality of an Oxisol and an Inceptisol in Mauritius. Communications in Soil Science and Plant Analysis 41(10):12051219. doi:dx.doi.org/ 10.1080/00103621003721403.

Collares, G.L., Reinert, D.J., Reichert, J.M., e Kaiser, D.R. 2008. Compactação de um Latossolo induzida pelo tráfego de máquinas e sua relação com o crescimento e produtividade de feijão e trigo. Revista Brasileira de Ciência do Solo 32(3):933942. doi:dx.doi.org/10.1590/S0100-06832008000300003. 
Cortez, J.W., Olszevisk, N., Pimenta, W.A., Filho, A.P.P., Souza, E.B., e Nagahama, H.J. 2014. Avaliação da intensidade do tráfego de tratores em alguns atributos físicos de um Argissolo Amarelo. Revista Brasileira de Ciência do Solo 38(3):10001010. doi:dx.doi.org/10.1590/S0100-06832014000300032.

Cunha, J.P.A.R., Cascão, V.N., e Reis, E.F. 2009. Compactação causada pelo tráfego de trator em diferentes manejos de solo. Acta Scientiarum Agronomy 31(3):371-375. doi:dx.doi.org/10.4025/actasciagron.v31i3.819.

Deperon Júnior, M.A., Nagahama, H.J., Olszevski, N., Cortez, J.W., e Souza, E.B. 2016. Influência de implementos de preparo e de níveis de compactação sobre atributos físicos do solo e aspectos agronômicos da cultura do milho. Revista Engenharia Agrícola 36(2):367-376. doi:dx.doi.org/10.1590/1809-4430-Eng.Agric.v36n2p367-376/2016.

Embrapa. 1997. Centro Nacional de Pesquisa de Solos. Manual de métodos de análise de solo. 212 p. Empresa Brasileira de Pesquisa Agropecuária (Embrapa), Brasília, Distrito Federal, Brasil.

Embrapa. 2011. Manual de métodos de análise de solo. 230 p. Empresa Brasileira de Pesquisa Agropecuária (Embrapa), Embrapa Solos, Brasília, Distrito Federal, Brasil.

Genro Júnior, S.A., Reinert, D.J., e Reichert, J.M. 2004. Variabilidade temporal da resistência do solo à penetração de um Latossolo Argiloso sob semeadura direta com rotação de culturas. Revista Brasileira de Ciência do Solo 28(3):477-484. doi:dx.doi.org/10.1590/S0100-06832004000300009.

Giarola, N.F.B., Brachtvogel, E.L., Fontaniva, S., Pereira, R.A., e Fioreze, S.L. 2009. Cultivares de soja sob plantio direto em Latossolo Vermelho compactado. Acta Scientiarum Agronomy 31(4):641-646. doi:dx.doi.org/10.4025/actasciagron.v31i4.851.

Hair, J.R., Anderson, R.E., Tatham, R.L., e Black, W.C. 2005. Análise multivariada de dados. 211 p. Bookman, Porto Alegre, Rio Grande do Sul, Brasil.

Kaiser, H.F. 1958. The varimax criterion for analytic rotation in factor analysis. Psychometrika 23(3):187-200.

Kemper, W.D., and Rosenau, R.C. 1986. Aggregate stability and size distribution. p. 425-441. In Klute, A. (ed.) Methods of soil analysis. $2^{\text {nd }}$ ed. American Society of Agronomy, Kimberly, Idaho, USA.

Lipiec, J., Horn, R., Pietrusiewicz, J., and Siczek, A. 2012. Effects of soil compaction on root elongation and anatomy of different cereal plant species. Soil and Tillage Research 121:74-81. doi:dx.doi.org/10.1016/j.still.2012.01.013.

Mantovanelli, B.C., Silva, D.A.P., Campos, M.C.C., Gomes, R.P., Soares, M.D.R., e Santos, L.A.C. 2015. Avaliação dos atributos do solo sob diferentes usos na região de Humaitá, Amazonas. Revista Ciências Agrárias 58(2):122-130. doi:dx.doi.org/10.4322/rca.1822.

Martins, S.G., Avanzi, J.C., Silva, M.L.N., Curi, N., Norton, and L.D., Fonseca, S. 2010. Rainfall erosivity and rainfall return period in the experimental watershed of Aracruz, in the coastal plain of Espirito Santo, Brazil. Revista Brasileira de Ciência do Solo 34(3):999-1004. doi:dx.doi.org/10.1590/S0100-06832010000300042.

Michelon, C.J., Carlesso, R., Petry, M.T., Melo, G.L., Spohe, R.B., e Andrade, J.G. 2009. Qualidade física dos solos irrigados de algumas regiões do Brasil Central. Revista Brasileira de Engenharia Agrícola e Ambiental 13(1):39-45. doi:dx.doi.org/10.1590/S1415-43662009000100006.

Obour, P.B., Kolberg, D., Lamande, M., Borresen, T., Edwards, G., Sorensen, C.G., et al. 2018. Compaction and sowing date change soil physical properties and crop yield in a loamy temperate soil. Soil and Tillage Research 184:153-163. doi:10.1016/j.still.2018.07.014.

Oliveira, I.A., Campos, M.C.C., Freitas, L., e Soares, M.D.R. 2015. Caracterização de solos sob diferentes usos na região sul do Amazonas. Acta Amazônica 45(1):1-12. doi:dx.doi.org/10.1590/1809-4392201400555.

Pacheco, L.P., São Miguel, A.S.D.C., Bonfim-Silva, E.M., Souza, E.D., e Silva, F.D. 2015. Influência da densidade do solo em atributos da parte aérea e sistema radicular de crotalária. Pesquisa Agropecuária Tropical 45(4):464-472. doi:dx.doi.org/10.1590/1983-40632015v4538107.

Pezzoni Filho, J.C., Fenner, P.T., Lanças, K.P., Pezzoni, D., Moraes, W.B., Chagas, H.A., et al. 2014. Compactação de um Cambissolo Háplico causada pela extração florestal com trator skidder. Cerne 20(2):199-208. doi: dx.doi.org/10.1590/01047760.201420021176.

Reichert, J.M., Reinert, D.J., e Braida, J.A. 2003. Qualidade dos solos e sustentabilidade de sistemas agrícolas. Revista Ciência e Ambiente 27:29-48.

Roque, A.A.O., Souza, Z.M., Barbosa, R.S., e Souza, G.S. 2010. Controle de tráfego agrícola e atributos físicos do solo em área cultivada com cana-de-açúcar. Pesquisa Agropecuária Brasileira 45(7):744-750. doi:dx.doi.org/10.1590/S0100-204X2010000700016.

Silva, F.A.Z., e Azevedo, C.A.V. 2002. Versão do programa computacional Assistat para o sistema operacional Windows. Revista Brasileira de Produtos Agroindustriais 4(1):71-78.

Soares, M.D.R., Campos, M.C.C., Oliveira, I.A., Cunha, J.M., Santos, L.A.C., Fonseca, J.S., et al. 2016. Atributos físicos do solo em áreas sob diferentes sistemas de usos na região de Manicoré, AM. Revista Ciências Agrárias 59(1):9-15. doi:dx.doi.org/10.4322/rca.2020.

Stefanoski,D.C.S.G.G., Marchão, R.L.,Petter,F.A.,e Pacheco, L.P. 2013. Uso e manejo do solo e seus impactos sobre a qualidade física. Revista Brasileira de Engenharia Agrícola e Ambiental. 17(12):1301-1309. doi:dx.doi.org/10.1590/S1415-43662013001200008.

Stolf, R. 1991. Teoria e teste experimental de fórmulas de transformação dos dados de penetrômetro de impacto em resistência do solo. Revista Brasileira de Ciência do Solo 15:229-235. doi:dx.doi.org/10.1590/S0100-06832014000300009. 
Suzuki, L.E.A.S., Reichert, J.M., Reinert, D.J., e Lima, C.L.R. 2007. Grau de compactação, propriedades físicas e rendimento de culturas em Latossolo e Argissolo. Pesquisa Agropecuária Brasileira 42(8):11591167. doi:dx.doi.org/10.1590/S0100-204X2007000800013.

Toledo, L.O., Anjos, L.H.C., Couto, W.H., Correia, J.R., Pereira, M.G., e Fernandes, M.E.C. 2009. Análise multivariada de atributos pedológicos e fitossociológicos aplicada na caracterização de ambientes de cerrado no norte de Minas Gerais. Revista Árvore 33(5):957-967. doi:dx.doi.org/10.1590/S0100-67622009000500018.

Tormena, C.A., Silva, A.P., e Libardi, P.L. 1998. Caracterização do intervalo hidrico ótimo de um Latossolo Roxo sob plantio direto. Revista Brasileira de Ciência do Solo 22(4):573-581. doi:dx.doi.org/10.1590/S0100-06831998000400002.

Valicheski, R.R., Grossklaus, F., Sturner, S.L.K., Tramontin, A.L., e Baade, E.S.A. 2012. Desenvolvimento de plantas de cobertura e produtividade da soja conforme atributos físicos em solo compactado. Revista Brasileira de Engenharia Agrícola e Ambiental 16(9):969-977. doi:dx.doi.org/10.1590/S1415-43662012000900007. 